\title{
THE IMPACT OF PRONIFER ${ }^{\circledR}$ SUPPLEMENTATION ON PERFORMANCE OF LACTATING EWES AND NEWBORN LAMBS UNDER UPPER EGYPT CONDITIONS
}

\section{A. Soliman}

Department of Animal Production, Faculty of Agriculture, Assiut University, Assiut 71526, Egypt

\section{SUMMARY}

The effects of Pronifer ${ }^{\circledR}$ on the performance of lactating ewes and their offspring were investigated in the present study. Twelve single-type of birth Saidi ewes with their lambs were divided into two similar groups according to their lambing date and weight of lamb. Animals were assigned randomly to either the control diet $(20 \%$ wheat straw and $80 \%$ concentrate mixture) or the experimental diet (the control diet plus Pronifer ${ }^{\circledR}$ at a rate of $3 \mathrm{~kg} / \mathrm{ton}$ of the concentrate mixture). The experiment lasted for 10 weeks starting at the $5^{\text {th }}$ day after lambing time. Milk yield as well as its fat and protein content were determined in the $3^{\text {rd }}, 4^{\text {th }}$ and $5^{\text {th }}$ week of lactation. Weighing lambs at birth and biweekly thereafter assessed their growth performance. At the end of experiment, blood samples were collected from ewes and lambs to determine some serum metabolites. Results indicated that ewes supplemented with Pronifer ${ }^{\circledR}$ in their diet tended to produce higher milk yield, protein percent and protein yield than untreated ones by $9.3,4.7$ and $14.6 \%$, respectively. However, fat percent and its yield tended to be lower by 24.9 and $13.2 \%$, respectively in the tested than the control group. Average daily gain of tested lambs was numerically higher (about $12 \%$ ) as compared with control lambs. Concentration of serum glucose and total cholesterol increased significantly $(\mathrm{P}<0.05)$ in the Pronifer ${ }^{\mathrm{B}}$-supplemented ewes and their offspring. Albumin concentration significantly $(\mathrm{P}<0.05)$ decreased while globulin concentration significantly $(\mathrm{P}<0.05)$ increased in blood serum of Pronifer ${ }^{\mathbb{B}}$ supplemented animals. It could be concluded from the present investigation that the use of the probiotic Pronifer ${ }^{\circledR}$ leads to improve the health status and feed utilization of both ewes and their lambs.

Keywords: Pronifer ${ }^{\circledR}$, ewes, lambs, milk, daily gain, blood metabolites

\section{INTRODUCTION}

Pronifer ${ }^{\circledR}$ is a probiotic agent, which composed of microorganisms or substances that contribute to the improvement in intestinal microbial balance (Lilly and Stillwell, 1965; Parker, 1974 and Fuller, 1989). Probiotics regulate the microbial environment of the intestine, decrease disturbances, inhibit pathogenic intestinal microorganisms and improve feed conversion efficiency (Windschitl, 1992 and Dhingra, 1993) with consequent improvement of animal health (Games, 1987 and Sisson, 1988) and increases of growth rates (Bohm and Srour, 1995). 
In addition, probiotics improve milk production (both yield and fat content) as a result of fungal supplementation such as $S$. cerevisiae or A. oryzae (Williams and Newbold, 1990). This may be a consequence of the observed effect on rumen metabolism.

Currently, considerable attention is being given to the use of probiotics in animal programs. Traditional probiotics are lactic acid bacteria such as Lactobacillus casein, Lactobacillus acidophilus and streptococci. Freter (1992) and Hughes and Heritage (2002) stated that probiotics are used when the indigenous microflora is incomplete, as in newborns, or disturbed by stress such as the administration of antibiotics.

In ruminants, the potential benefits of probiotics may be obtained by enhancing the rate at which the rumen flora and fauna develop in young ruminants or by stimulating fermentation in adult ruminants (Wallace and Newbold, 1992).

Nahashon et al. (1992) pointed out that composition of probiotic is mono or mixed culture of living microorganisms applied to the animal or man, which beneficially affect the host by improving the properties of indigenous microflora.

Commercial probiotics (Pronifer ${ }^{\circledR}$ ) as a feed additive during the growth stage of lambs and ewes (after parturition) was not examined for growth performance, milk yield and its constituents and some blood serum metabolites under Upper Egypt conditions. Therefore, the objective of this trial was undertaken to throw a light on the effect of supplemental Pronifer ${ }^{\circledR}$ on growth performance and some blood serum metabolites of ewes and their offspring. In addition, ewes milk yield and its constituents were also studied.

\section{MATERIALS AND METHODS}

Pronifer $^{\circledR}$ was identified by P.G.E. (EGGER, GmbH, Milter labill, Austria) as a feed additive made by specific lactic acid fermentation of heat-treated soybean meal and malt, using a multiple-strain mixture of Lactobacilli and Pediococcus, selected from their natural habitat. It contains: 1) viable lactic acid bacteria of approx. $10^{6}$ colony forming units (CFU) per gram (L. plantarum, L. fermentum, L. brevis, L. casei and Pediococcus acidilactici); 2) lactic acid fermentation metabolites and enzymes; and 3) free amino acids and short-chain peptides. Pronifer ${ }^{\circledR}$ contains $48 \% \mathrm{CP}, 44 \%$ DCP, $1 \%$ ether extract and $7 \%$ ash on DM basis.

\section{Animals and experimental design:}

The experiment was carried out at the Experimental Farm of Animal Production Department, Faculty of Agriculture, Assiut University, Assiut, Egypt.

Twelve single-type of birth Saidi ewes with their lambs were divided into two similar groups according to their lambing date and weight of lamb and randomly assigned to the control and experimental group. Each group of ewes was housed with their lambs in a $8 \times 12 \mathrm{~m}$ pen. The daily energy and protein requirements were calculated as explained by the NRC (1985). Ewes were fed $20 \%$ of their daily allowance as wheat straw (WS) and $80 \%$ as a concentrate mixture (CM). The concentrate mixture consisted of $77 \%$ ground yellow corn, $20 \%$ soybean meal, $2 \%$ lime stone, $1 \%$ common salt (sodium chloride) and trace minerals mixture at a rate of $3 \mathrm{~kg} / \mathrm{ton}$ of the CM. Each $100 \mathrm{~g}$ of the mineral mixture contains $25.6 \mathrm{~g} \mathrm{Na}, 4.6 \mathrm{~g} \mathrm{Ca}$, $1.8 \mathrm{~g} \mathrm{P}, 1.6 \mathrm{~g} \mathrm{~K}, 300 \mathrm{mg} \mathrm{Fe}, 40 \mathrm{mg} \mathrm{Mg}, 32 \mathrm{mg} \mathrm{Mn}, 15 \mathrm{mg} \mathrm{I}, 10 \mathrm{mg} \mathrm{Mo}$, 9mg Ni, $5 \mathrm{mg} \mathrm{Zn}$, $1.5 \mathrm{mg} \mathrm{Cu}, 1 \mathrm{mg} \mathrm{Co}$ and $1 \mathrm{mg}$ Se. Proximate analysis of $\mathrm{CM}$ and WS was determined 
according to A.O.A.C. (1975). The chemical composition and nutritive value of WS and CM are shown in Table (1). The control group fed WS and CM as described above, while the experimental group supplemented with Pronifer ${ }^{\circledR}$ at a rate of 3 $\mathrm{kg} /$ ton of the CM. Each group was fed the assigned diet at the $5^{\text {th }}$ day after lambing (to allow the newborn lambs suckling colostrum) and continued for 10 weeks thereafter. Both groups were kept under the same environmental and managerial conditions. Clean drinking water was freely available at all times.

Table 1. Chemical composition and nutritive value of the concentrate mixture (CM) and wheat straw (WS)

\begin{tabular}{lcc}
\hline Item & \multicolumn{2}{c}{$\%$} \\
\cline { 2 - 3 } & CM & WS \\
\hline Chemical analysis (on DM basis): & 16.83 & 4.62 \\
Crude protein & 4.57 & 44.72 \\
Crude fiber & 2.63 & 1.89 \\
Ether extract & 5.90 & 9.25 \\
Ash & 70.07 & 39.52 \\
Nitrogen free extract & & \\
& & \\
Nutritive value ${ }^{1}$ : & 81.91 & 36.84 \\
TDN & 12.94 & -2.26 \\
DCP
\end{tabular}

1- nutritive values of CM were calculated from nutritive values of its ingredients while those of WS were as reported by Soliman et al. (2002).

\section{Milk sampling and analysis:}

Three milk samples were taken from each ewe in the $3^{\text {rd }}, 4^{\text {th }}$ and $5^{\text {th }}$ week of lactation. Milk yields of ewes were estimated using the weighing-suckling technique as described by Economides (1987). According to this technique, lambs were separated from their dams and allowed to suckle 3 times daily. At each suckling, lambs were weighed before and after suckling. The difference in weights representing the amount of milk consumed. After the last suckling, ewes were milked by hand to remove any surplus milk. The milk suckled plus the amount of surplus milk is the total daily milk yield of ewes. Milk fat percentage was determined by the standard Gerber method, while milk protein content was determined by following the Kjeldahl procedure (A.O.A.C., 1975). Feed efficiency was calculated as Mcal energy value of milk $\left(\mathrm{EV}_{1}\right)$ per Mcal digestible energy intake (DEI). The $\mathrm{EV}_{1}$ was calculated as a function of fat content and days in lactation utilizing the equations recommended by the AFRC (1993) while the DEI was calculated according to the NRC (1985).

Lamb growth performance:

Lambs were fasted overnight then weighed before the morning feeding. Weights were recorded at birth and biweekly thereafter. Total and daily live weight gains were calculated for the whole experimental period. Feed efficiency was calculated as Mcal energy value of gain $\left(\mathrm{EV}_{\mathrm{g}}\right)$ per Mcal $\mathrm{EV}_{\mathrm{l}}$. Energy value of gain $\left(\mathrm{EV}_{\mathrm{g}}\right)$ was calculated according to the AFRC (1993). 


\section{Blood sampling and analysis:}

At the end of experiment, blood samples $(5 \mathrm{ml})$ from each ewe and lamb were collected from the jugular vein into dry glass tube and allowed to clot at room temperature for 30 minutes. Blood sera were separated by centrifugation at $3000 \mathrm{rpm}$ for 15 minutes, decanted into plastic vials and stored at $-20^{\circ} \mathrm{C}$ until the time of assay. Some metabolic profiles such as glucose, total cholesterol, total protein, albumin, urea-N, aspartate aminotransferase (AST) and alanine aminotransferase (ALT) were determined by using calorimetric assay kits. Total globulin was calculated by difference between serum total protein and albumin.

\section{Statistical analysis:}

Data on ewes' milk and lambs growth performance were tested using the twosample t-test procedure provided by the STATISTIX program (Analytical Software, 1994). Blood serum constituents of ewes and lambs were statistically analyzed using the GLM procedure of SAS (1996). Treatment and ewe-lamb effects were examined utilizing the two-way ANOVA (Steel and Torrie, 1980). The statistical model was:

$$
\text { Yijk }=\mu+\mathrm{Ti}+\mathrm{Aj}+\mathrm{TAij}+\text { Eijk }
$$
Where:

Yijk = Serum constituent of animal in its treatment.

$\mu=$ General mean

$\mathrm{Ti}=$ Treatment effect; $\mathrm{i}=1,2$

Aj = Animal effect; $\quad \mathrm{j}=$ Ewe, Lamb

TAij = Interaction between treatment effect and animal effect

Eijk $=$ Random error

Differences between means of the main effects and interaction were tested utilizing the GLM procedure of SAS (1996) for mean separation.

\section{RESULTS AND DISCUSSION}

\section{Milk yield and its constituents:}

Results in Table (2) indicate that ewes fed the experimental diet tended to produce higher milk yield, protein percent and protein yield than the other group by 9.3, 4.7 and 14.6\%, respectively. Abou'l Ella et al. (2003) obtained similar results on Rahmani ewes fed diets supplemented with Pronifer ${ }^{\circledR}$ at a rate of $10 \mathrm{gm} / \mathrm{head} / \mathrm{day}$. However, fat percent and its yield tended to decrease by 24.9 and $13.2 \%$, respectively. Elevation in milk and protein yields are considered to be an indicator that treated ewes were in a good health and better condition than control ewes.

Sisson (1988) reported that supplementation with probiotic organisms gives a daily protection against any pathogens that may get entrance to the animal gut. This protection improves the digestion and absorption processes of the essential nutrients giving rise to better feed utilization by the animal. Improved feed utilization enhances milk secretion and increases milk yield. Since both of groups consumed similar amounts of feed (Table 2), the control group showed higher body weight change $(+2.1 \mathrm{~kg})$ than Pronifer $^{\mathbb{B}}$-supplemented group $(+0.04 \mathrm{~kg})$. This means that Pronifer ${ }^{\mathbb{B}}-$ supplementation was in favor of milk production while it was at expense of body weight gain. 
Table 2. Effect of Pronifer ${ }^{\circledR}$ supplementation on milk yield and composition, feed efficiency and body weight change of ewes throughout the experimental period

\begin{tabular}{lcc}
\hline Item & Control & Pronifer $^{\circledR}$ \\
\hline Milk yield, g/d & $894.33 \pm 52.90$ & $977.67 \pm 5.33$ \\
Fat, \% & $6.46 \pm 0.91$ & $5.17 \pm 0.36$ \\
Fat yield, g/d & $57.77 \pm 5.83$ & $50.55 \pm 3.35$ \\
Protein, \% & $4.67 \pm 0.24$ & $4.89 \pm 0.47$ \\
Protein yield, g/d & $41.76 \pm 3.43$ & $47.81 \pm 4.84$ \\
Feed intake, kg DM/d & 1.41 & 1.41 \\
Feed efficiency: & & \\
$\quad$ Kg milk/kg DMI & 0.63 & 0.69 \\
$\quad$ Mcal EV $/$ Mcal DEI & 0.21 & 0.21 \\
Body weight change, kg & +2.1 & +0.04 \\
\hline
\end{tabular}

$\mathrm{DMI}=$ dry matter intake; $\mathrm{EV}_{1}=$ energy value of milk; $\mathrm{DEI}=$ digestible energy intake.

\section{Lambs growth performance:}

Results illustrated in Table (3) and Figure (1) show that growth rate of lambs affected insignificantly $(\mathrm{P}>0.05)$ by Pronifer ${ }^{\circledR}$ supplementation. However, body weight and daily gain increased gradually during the experimental period (10 weeks). At the end of the trial, average body weight and daily gain of lambs fed the supplemented diet were numerically higher by $8.9 \%$ and $11.9 \%$, respectively than those fed the control diet. High body weight and daily gain of treated lambs may be attributed to the higher intake of milk from their mothers (Table 3), where data of milk yield showed that milk yield of treated ewes increased by $9.3 \%$ as compared to untreated ewes. The probiotic Pronifer ${ }^{\circledR}$ is composed mainly of lactobacillus bacterial cocktail that improved the balance of intestinal microflora and consequent improvement in the digestion process reaching to an efficient digestion and feed utilization. These effects were reflected on the overall performance of treated lambs in the form of good appearance, higher activity and an increase in live body weight and daily gain.

Fuller and Booker (1974) mentioned that lactobacilli affected the balance of enteric organisms and improved weight gain. Manickam et al. (1994) found that performance (weight gain and feed conversion) of broilers given lactobacilli was significantly better than untreated controls.

Assuming that lambs are the target of production during the experimental period, the economic return could be calculated utilizing the data of feed intake (Table 2 ) and total gain (Table 3$)$. Pronifer $^{\circledR}$ costs 5.03 L.E. $(1.41 \times 3 \times 70 \times 1.7)$ while the price of total gain due to the treatment is 16.8 L.E. $(1.2 \times 14)$. Therefore, the economic return from Pronifer ${ }^{\circledR}$ supplementation is 11.77 L.E. per lamb (9.81 L.E. / kg live body weight gain). 
Table 3. Effect of Pronifer ${ }^{\circledR}$ supplementation on live weight, daily gain and feed efficiency of lambs

\begin{tabular}{lcr}
\hline Item & Control & Pronifer $^{(B)}$ \\
\hline Initial body weight, $\mathrm{kg}$ & $3.12 \pm 0.33$ & $3.18 \pm 0.25$ \\
Final body weight, kg & $13.20 \pm 1.87$ & $14.38 \pm 1.27$ \\
Total gain, kg & $10.08 \pm 1.68$ & $11.28 \pm 1.17$ \\
Daily gain, g & $144.00 \pm 24.02$ & $161.14 \pm 16.71$ \\
Feed efficiency: & & \\
$\quad$ Kg gain/kg milk & 0.16 & 0.17 \\
$\quad$ Mcal EV $/$ /Mcal EV & 0.28 & 0.34 \\
\hline EV $=$ energy value of gain; $\mathrm{EV}_{1}=$ energy value of milk &
\end{tabular}

$\mathrm{EV}_{\mathrm{g}}=$ energy value of gain; $\mathrm{EV}_{1}=$ energy value of milk.

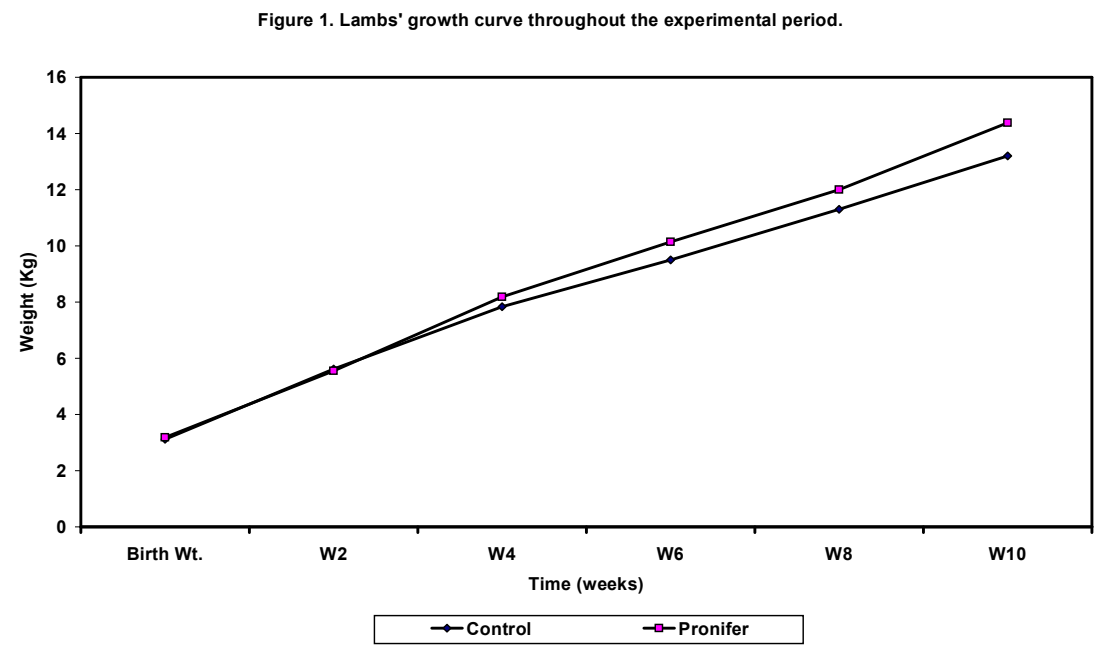

Serum metabolites changes:

Studies on the effect of Pronifer ${ }^{\circledR}$, as a probiotic supplement, on serum metabolites of ewes and lambs are lacking. In the present trial, concentration of serum glucose for treated ewes and lambs was significantly $(\mathrm{P}<0.01)$ higher by 11.8 and $19.2 \%$, respectively than untreated ones (Table 4). This increase may be due to that Pronifer ${ }^{\circledR}$ feeding may increase propionate production in the rumen (McDonald et al., 1995). Much of propionate produced in the rumen is absorbed and transformed to glucose in the liver. Higher levels of glucose are then released into the peripheral circulation. Bergman (1983) reported that propionate is a potent glycogenic compound and can account for about two-thirds of total glucose produced in animals fed large amount of concentrates. In general, the increase in both serum levels of glucose and growth rate indicated that treated ewes and their offspring were in better condition than untreated ones.

In the present study, concentration of serum total cholesterol in Pronifer ${ }^{\circledR}$-treated ewes and their offspring increased $(\mathrm{P}<0.05)$ by 50.8 and $61.4 \%$, respectively. The higher values of total cholesterol levels in treated group may be due to the improvement of ether extract digestibility by Pronifer ${ }^{(B)}$ supplementation. Jin et al. 
(1997) reported that the use of probiotics stimulate appetite and digestion and eventually increase fat retention. Another explanation for increasing total cholesterol concentration may be attributed to the higher absorption of dietary lipids and hence energy available for anabolism and fat synthesis processes. This is confirmed by Stullwbeam et al. (1969) who reported that lower energy intake by beef heifers resulted in a lower serum cholesterol level.

Table 4. Effect of Pronifer ${ }^{\circledR}$ supplementation on some blood serum metabolites of ewes and lambs

\begin{tabular}{|c|c|c|c|c|c|c|}
\hline \multirow[t]{2}{*}{ Item } & \multicolumn{2}{|c|}{ Ewes } & \multicolumn{2}{|c|}{ Lambs } & \multirow[t]{2}{*}{$P$} & \multirow[t]{2}{*}{ SEM } \\
\hline & Control & Pronifer $\left.^{(}\right)$ & Control & Pronifer $^{\circledR}$ & & \\
\hline Glucose, mg/dl & $30.34 c$ & $33.93 b c$ & $45.22 a b$ & $53.90 a$ & $<0.01$ & 6.22 \\
\hline Cholesterol, mg/dl & $64.93 a b$ & $97.89 a$ & $30.00 b$ & $48.41 a b$ & $<0.05$ & 25.23 \\
\hline Total protein, g/dl & 12.09 & 11.14 & 10.91 & 12.03 & NS & 0.78 \\
\hline Albumin, $\mathrm{g} / \mathrm{dl}$ & $4.89 a$ & $3.43 b c$ & $4.40 a b$ & $3.31 c$ & $<0.05$ & 0.50 \\
\hline Globulin, g/dl & $7.20 a b$ & $7.71 a b$ & $6.51 b$ & $8.72 a$ & $<0.05$ & 1.01 \\
\hline Urea-N, mg/dl & $45.79 a b$ & $39.51 b$ & $56.06 a$ & $52.56 a b$ & $<0.05$ & 7.79 \\
\hline $\mathrm{AST}, \mathrm{U} / 1$ & 70.82 & 68.61 & 72.36 & 84.40 & NS & 8.21 \\
\hline ALT, U/1 & $6.53 b c$ & $5.07 c$ & $11.18 a b$ & $13.19 a$ & $<0.01$ & 2.43 \\
\hline
\end{tabular}

Results in Table (4) indicate that serum total protein concentration increased insignificantly $(\mathrm{P}>0.05)$ by $10.27 \%$ in treated lambs while the reverse effect was observed in treated ewes as compared to control ones. In respect to lambs, such increase may be attributed to the good effect of Pronifer ${ }^{\circledR}$ in preventing diseases that usually lead to a great loss of body proteins. Sisson (1988) pointed out that probiotic addition improved animal health by preventing diarrhea and increasing animal growth rate. In addition, lactobacillus bacteria, which presented in the Pronifer ${ }^{\circledR}$ enhanced growth and improved animal health (Chateau et al., 1993). Another explanation is that the addition of Pronifer ${ }^{\circledR}$ to the lambs ration increases the rumen microbial protein synthesis (Abou'l Ella et al., 2003) and crude protein digestibility, which possibly increased total protein in serum of Pronifer ${ }^{\mathbb{R}}$-treated lambs. It is not surprising to notice that concentration of total globulin increased significantly $(\mathrm{P}<0.05)$ by 6.6 and $33.9 \%$ in treated ewes and their offspring, respectively (Table 4). For this reason, Pronifer ${ }^{\circledR}$ supplementation had a positive effect on the health status of animals (Chateau et al., 1993) due to the elevation of immune system in the body. Shoeib et al. (1996) found an enhancement effect to the humoral immune response in broiler chicks treated with Pronifer ${ }^{\circledR}$ as it increased the number of activated Blymphocytes and plasma cells in the spleen and bursa of the treated birds. Also, Miake et al. (1985) stated that lactobacilli are potent immuno-stimulants through enhancement of humoral and cellular immune response.

Elevation in AST and ALT are considered to be a good indicator of liver dysfunction (Sheriock, 1975). Lambs fed Pronifer ${ }^{\circledR}$-supplemented diet had higher serum transferases (AST and ALT) concentrations than those fed control diet (Table 4) by 16.6 and $17.99 \%$, respectively while the reverse effect was observed in ewes. This increase may be attributed to the increased synthesis of these enzymes in response to the increased need for glyconeogenesis. AST and ALT enzymes are 
important in glucose synthesis from non-carbohydrate metabolism sources (Harper et al., 1977).

Results in Table (4) revealed that ewes and lambs fed Pronifer ${ }^{\circledR}$ supplemented diet tended to have lower $(\mathrm{P}<0.05)$ serum urea- $\mathrm{N}$ concentration by 15.89 and $6.66 \%$ than control ewes and lambs, respectively. The decrease in serum urea-N concentration in response to Pronifer ${ }^{\mathbb{B}}$ supplementation may be attributed to the decrease in ammonia production in the digestive tract. Chateau et al. (1993) recorded that lactobacillus bacteria present in the Pronifer ${ }^{\circledR}$ suppress ammonia production in the intestine.

\section{CONCLUSION}

It could be concluded from the present investigation that the use of the probiotic Pronifer ${ }^{\circledR}$ leads to improve the health status and feed utilization of both ewes and their lambs. Increasing both milk production of ewes and body weight gain of lambs manifested this improvement. In addition, immune systems of ewes and lambs were in better conditions, which reflected in protection against pathogens. However, a recent report from the Scientific Committee for Animal Nutrition (SCAN, 2001), concerning the safety of Pronifer ${ }^{\circledR}$, found that two of the principal strains within the product, Pediococcus acidilactici and Lactobacillus plantarum, were resistant to tetracyclines. Because of the possible dissemination of tetracycline resistance genes in animal bacterial populations, the food chain and the environment, SCAN (2001) considered that Pronifer ${ }^{\circledR}$ poses a risk when used in animal nutrition.

\section{REFERENCES}

Abou'l Ella, A. A., A. N. Sayed, S. G. Abdo and M. M. Khorshed, 2003. Effect of commercial probiotic supplementation on the productive performance of lactating ewes. Egyptian J. Nutrition and Feeds 6 (Special Issue):1023.

AFRC, 1993. Energy and Protein Requirements of Ruminants. An advisory manual prepared by the AFRC Technical Committee on Responses to Nutrients. CAB INTERNATIONAL, Wallingford, UK.

Analytical Software. 1994. STATISTIX, version 4.1. Analytical software, Tallahassee, FL 32317-2185 USA.

A.O.A.C. 1975. Official Methods of Analysis. $12^{\text {th }}$ Ed., Association of Official Analytical Chemists, Washington, DC 20044.

Bergman, E. N., 1983. The pools of cellular nutrients: Glucose. In: Dynamic Biochemistry of Animal Production. Riis, P. M. (Ed.), pp. 173-196. Elsevier, Amsterdam.

Bohm, J. and A. Srour, 1995. An Austrian probiotic feed additive for Egyptian buffalo and cattle production. $3^{\text {rd }}$ Sci. Cong. Egypt. Soc. for Cattle Diseases., 3-5 Dec.

Chateau, N., I. Castellanos and A. M. Deschamps, 1993. Distribution of pathogen inhibition in the bacillus isolates of a commercial probiotic consortium. J. Applied Bact. 74:36.

Dhingra, M. M., 1993. Probiotics in poultry diet. Poultry Adviser. 26(8):43. 
Economides, S., 1987. Sheep and goat production research and development in Cyprus. In: Small Ruminants in the Near East. FAO, Anim. Prod. Health, pp. 5974.

Freter, R., 1992. Factors affecting the microbiology of the gut. In: Probiotics: The scientific basis. R. Fuller, $1^{\text {st }}$ Ed., pp. 111-144. Chapman \& Hall, 2-6 Boundary Row, London SE1 8HN.

Fuller, R., 1989. Probiotics in man and animals. J. Applied Bact. 66:636.

Fuller, R. and B. E. Booker. 1974. Lactobacilli which attach to the crop epithelium of the fowl. Am. J. Clin. Nutr. 27:1305.

Games, R. G., 1987. Animal nutrition and feeding. $1^{\text {st }}$ Ed., Text Book, Demar Publisher Inc., USA.

Harper, M. A., V. W. Rodwell and P. A. Mayer, 1977. Review of physiological chemistry. $16^{\text {th }}$ Ed. Lange Medical Publications, California, pp. 76, 454, 569-570.

Hughes, P. and J. Heritage. 2002. Antibiotic growth-promoters in food animals.http://www.fao.org/DOCREP/ARTICLE/AGRIPPA/555_EN.HTM.

Jin, L. Z., Y. W. Ho, N. Abdullah and S. Jalaludin, 1997. Probiotic in poultry, modes of action. World's Poultry Sci. J. 53:352.

Lilly, D. M. and R. H. Stillwell, 1965. Probiotics, growth promoting factors produced by microorganisms. Sci. 147:747.

Manickam, R., K. Viswanathan and M. Mohan, 1994. Effect of probiotics on broiler performance. Indian Vet. J. 71:737.

McDonald, P., R. A. Edwards and J. F. D. Greenhalgh, 1995. Animal nutrition. $5^{\text {th }}$ Ed. Longman group Ltd., UK.

Miake, S., K. Nomoto, T. Yokokura, Y. Yoshikai, M. Mutai and K. Nomoto, 1985. Protective effect of $\mathrm{L}$. casei on Psedomonas aeruginosa infection in mice. Infection and Immunity. 48:480.

Nahashon, S. N., H. S. Nakaue and L. W. Mirosh, 1992. Effect of direct fed microbials on nutrient retention and production parameters of laying pullets. Poultry Sci. 71:111.

NRC, 1985. Nutrient requirements of sheep. Sixth Ed. National Academy of Sciences, National Research Council, Washington, DC.

Parker R. B., 1974. Probiotic, the other story of antibiotic story. Animal Nutrition and Health. 29:4.

SAS, 1996. SAS User's Guide, Statistics (version 6.2 Ed.). Cary NC, SAS Institute Inc.

SCAN, 2001. Scientific Committee for Animal Nutrition: Report on the use of certain microorganisms as additives in feedstuffs. http://europa.eu.int/comm/food/fs/sc/scan/out58_en.pdf

Sheriock, S., 1975. Disease of the liver and biliary system. $5^{\text {th }}$ Ed. Oxford, Blackwell Sci. Pub.

Shoeib, H. K., A. N. Sayed, S. A. Sotohy and S. Kh. Abdel-Ghaffar, 1996. Response of broiler chicks to probiotic (Pronifer) supplementation. Assiut Vet. Med. J. 36:103.

Sisson, J. W. 1988. Potential of probiotic organisms to prevent diarrhea and promote digestion in farm animals. J. Food and Agric. Sci. 49:1.

Soliman, I. A., M. M. Farghly, G. A. Abd El-Hafez and S. M. Mousa, 2002. Sugarcane tops silage as ruminants feedstuff: 1- Chemical composition, silage 
quality and nutritive value. Proceeding of the $1^{\text {st }}$ Ann. Sc. Conf. Anim. \& Fish Prod. PP. 41-60, Mansoura 24\&25 Sept., Mansoura University, Egypt.

Steel, R. G. D. and J. H. Torrie, 1980. Principles and procedures of statistics: A biometrical approach. $2^{\text {nd }}$ Ed., McGraw-Hill Book Co., New York.

Stullwbeam, C. F., J. E. Blakely, J. E. Lasley, G. B. Thompson and D. T. Hayer, 1969. Effect of energy intake upon the levels contain blood components - young beef heifers. J. Anim. Sci. 23:992.

Wallace, R. J. and C. J. Newbold, 1992. Probiotics for ruminants. In: Probiotics: The scientific basis. R. Fuller, $1^{\text {st }}$ Ed., pp. 317-353. Chapman \& Hall, 2-6 Boundary Row, London SE1 8HN.

Williams, P. E. V. and C. J. Newbold, 1990. Rumen probiosis: The effects of novel microorganisms on rumen fermentation and ruminant productivity. In: Recent advances in animal nutrition. W. Haresign and D. J. A. Cole, Eds, pp. 211-227. Butterworth, London.

Windschitl, P. M., 1992. Effects of probiotic supplementation of hulless barley and corn based diets on bacterial fermentation in continuous culture of ruminal contents. Can. J. Anim. Sci. 72:265. 
تأثير إضافة البرونيفير على أداء النعاج الحلابة والحملان حديثة الولادة تحت ظروف صعيد مصر

إبراهيم عبد الله سليمان

قسم الإتتاج الحيوانسي-كلية النراعة-جامعة أسيوط-أسيوط 4 ب 1 V V-مصر

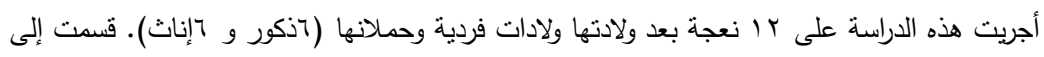

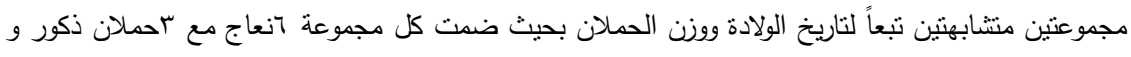

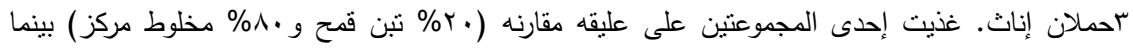

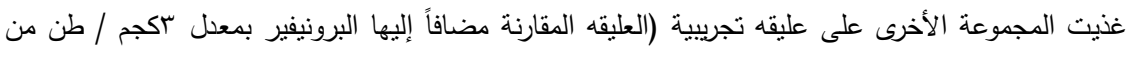

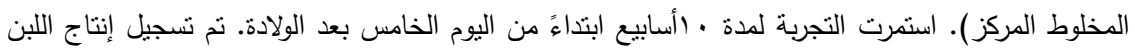

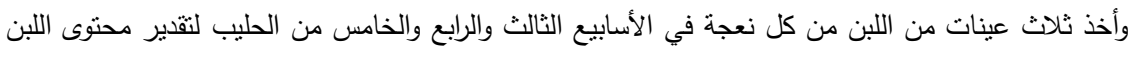

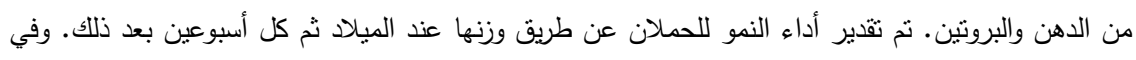

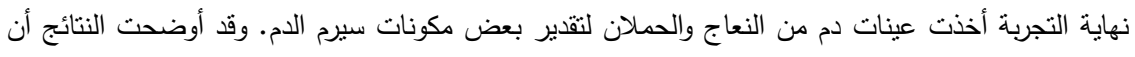

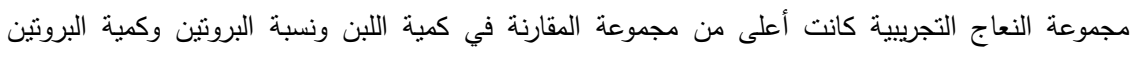

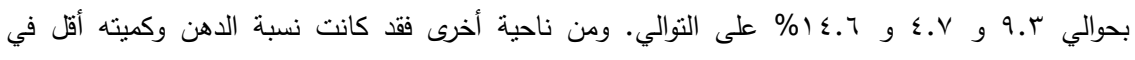

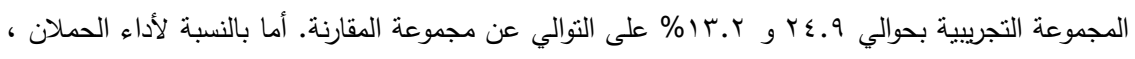

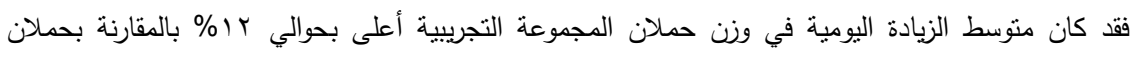

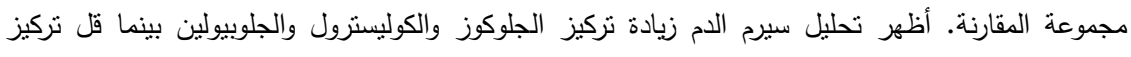

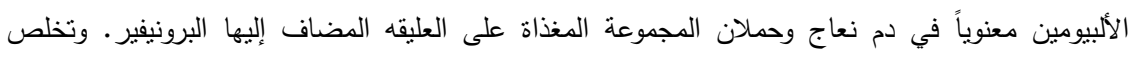

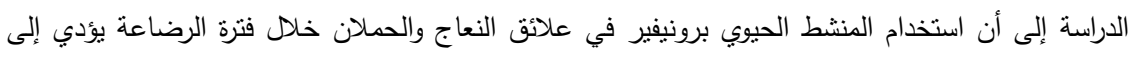
تحسين حالتها الصحية وزيادة معدل الاستفادة من الغذاء. 